\title{
Wybrane środki służące zapewnieniu dostępności cyfrowej dla osób z niepełnosprawnościami
}

\author{
Anna Rogacka-Łukasik \\ Uniwersytet Humanistyczno-Przyrodniczy \\ im. Jana Długosza w Częstochowie \\ arogacka@tlen.pl \\ ORCID: https://orcid.org/0000-0001-6140-0591
}

\section{Wstęp}

Niepełnosprawność jest zjawiskiem wielowymiarowym, które dotyka wiele osób niezależnie od płci, wieku czy innych czynników, dlatego też należy na nią patrzeć nie tylko przez pryzmat natury medycznej, ale i społecznej ${ }^{1}$. Na płaszczyźnie społecznej kluczowe jest dążenie do poszerzenia samodzielności życiowej osób $\mathrm{z}$ niepełnosprawnościami. Wyniki badań demograficznych pokazują, iż coraz większa część populacji to ludzie o różnych formach niepełnosprawności oraz ludzie starzy - starzenie się jest przecież związane $\mathrm{z}$ występowaniem różnych dysfunkcji fizycznych i psychicznych, a więc w konsekwencji znacznym wzrostem liczby osób $\mathrm{z}$ niepełnosprawnościami. Wobec powyższego dążenie do opracowania i wprowadzenia do praktyki rozwiązań, które pomogą uzyskać osobom z niepełnosprawnościami samodzielność życiową, jest konieczne ${ }^{2}$.

W rekomendacjach Raportu Polska 2030. Wyzwania rozwojowe (dalej: Raport Polska $)^{3} \mathrm{w}$ ramach stworzonego modelu zwiększenia spójności społecznej w Polsce wskazano m.in., iż niezbędne jest podjęcie szeregu działań na rzecz osób z niepełnosprawnościami, w tym „przygotowanie się na nowe oblicza wykluczenia społecznego, które już obecnie występują w innych krajach i nieuchronnie pojawią się

\footnotetext{
1 M. Karaś, Niepełnosprawność, od spojrzenia medycznego do społecznego $i$ disability studies, „Przegląd Prawny, Ekonomiczny i Społeczny" 2012, nr 4, s. 31-32.

2 B. Gąciarz, W kierunku nowego modelu polityki społecznej, [w:] Polacy niepełnosprawni. Od kompleksowej diagnozy do modelu polityki społecznej, red. B. Gąciarz, S. Rudnicki, Kraków 2014, s. 377.

3 http://www.zbp.pl/photo/jacek/klub_polska_2015_polska_2030/ZBP_V.03.pdf [dostęp: 9.12.2020].
} 
również w Polsce. Można tu wymienić na przykład wykluczenie cyfrowe". W dalszej części raportu Zespół Doradców Strategicznych Prezesa Rady Ministrów RP wskazuje, iż wykluczenie cyfrowe może stanowić deficyt nawet u osób wykształconych, które nie będą w stanie nadążać za postępem technologicznym w zakresie wymiany informacji ${ }^{4}$, a więc na pewno sprawi trudności osobom $\mathrm{z}$ niepełnosprawnościami. W związku z tym należy podkreślić, iż nieodzownym elementem takich działań są zabiegi legislacyjne, które wpłyną na sposób realizacji działań na rzecz osób $\mathrm{z}$ niepełnosprawnościami.

Podstawę funkcjonowania obywateli w społeczeństwie, bez względu na swoją odmienność polityczną, społeczną czy - w przypadku osób z niepełnosprawnościami - na różnice wynikające $\mathrm{z}$ ich ograniczeń w mobilności i percepcji, stanowi art. 32 ust. 2 Konstytucji $\mathrm{RP}^{5}$, wedle którego, „nikt nie może być dyskryminowany w życiu politycznym, społecznym lub gospodarczym z jakiejkolwiek przyczyny. Regulację art. 32 ust. 2 Konstytucji RP traktuje się w orzecznictwie Trybunału Konstytucyjnego ${ }^{6}$ jako „całość normatywną", która gloryfikuje wymienioną zasadę niedyskryminacji jako zasadę ogólną ${ }^{7}$. Wydawałoby się, że ww. postanowienie ustawy zasadniczej (analogiczne w innych państwach europejskich) wystarczy dla normalizacji życia osób z niepełnosprawnościami. Jednak potrzeba zabezpieczenia praw szczegółowych, zwłaszcza w zakresie dostępności, wymusiła powstawanie następnych aktów prawnych, uwzględniających prawa osób z niepełnosprawnościa$\mathrm{mi}^{8}$. Jednym $\mathrm{z}$ aktów upowszechniających dostępność - nie tylko fizyczną środowiska zabudowanego, ale również dostęp do informacji, dostęp do usług, dostępność przestrzeni publicznej dla osób z niepełnosprawnościami - jest Deklaracja barcelońska, przyjęta podczas Europejskiego Kongresu „Miasto i niepełnosprawni”, który miał miejsce w Barcelonie 23-24 marca 1995 r. ${ }^{9}$ W Polsce Deklarację barcelońską jako pierwsze miasto przyjęła Gdynia podczas V kadencji sesji Rady Miasta Gdynia w 28 kwietnia 2010 r. Wtedy to jednogłośnie przyjęto, że dokument ten w pełni odpowiada polityce społecznej Gdyni, która ma na celu pełne włączenie osób z niepełnosprawnościami w życie miasta i traktowanie ich jako pełnoprawnych partnerów we wszystkich dziedzinach życia ${ }^{10}$. Innym aktem prawnym, mającym na celu zwiększenie dostępności publicznej dla osób z niepełnosprawnościami,

4 Raport Polska 2030. Wyzwania rozwojowe, red. M. Boni, Warszawa 2009, s. 294-295.

$5 \quad$ Konstytucja Rzeczypospolitej Polskiej z dnia 2 kwietnia 1997 r. (Dz.U. z 1997 r. Nr 78, poz. 483 z późn. zm.).

$6 \quad$ Wyrok TK z dnia 24 października 2001 r., SK 22/01, OTK 2001, nr 7, poz. 216.

$7 \quad$ Konstytucja RP. T. 1, Komentarz: art. 1-86, red. M. Safijan, L. Bosek, Warszawa 2016.

8 J. Konarska, Bariery aktywności psychospołecznej osób z niepełnosprawnością - mity i rzeczywistość, „Przegląd Badań Edukacyjnych” 2015, nr 21, s. 155-156.

9 M. Wysocki, Projektowanie uniwersalne - równość praw poprzez dostępność, [w:] Najważniejsze wyzwania po ratyfikacji przez Polskę Konwencji ONZ o Prawach Osób Niepełnosprawnych, „Biuletyn Rzecznika Praw Obywatelskich" 2012, nr 10, s. 30.

10 Zob. Po 42. sesji Rady Miasta Gdyni, Gdynia. Moje miasto, 6.05.2010, https://www.gdynia.pl/mieszkaniec/951-551-2010-0507-2010-05-13,3239/po-42-sesji-rady-miasta-gdyni,397335 [dostęp: 2.07.2019]. 
Wybrane środki służące zapewnieniu dostępności cyfrowej...

jest tzw. Agenda 22, czyli Local Autohorities (2001), opracowany przez skandynawskie organizacje osób z niepełnosprawnościami. Aktów prawnych zapewniających dostępność publiczną dla osób z niepełnosprawnościami można wymienić jeszcze kilka, jednak nie stanowią one meritum niniejszej publikacji, a jedynie w ramach wprowadzenia w zagadnienie szeroko rozumianej dostępności wskazano dwa wyżej wymienione.

Istotne natomiast, jest to, iż ustawodawca podąża dalej. Wychodząc naprzeciw intensywnemu rozwojowi nowych technologii, formułuje kolejne akty prawne, $\mathrm{w}$ których gwarantuje korzystanie $\mathrm{z}$ tych technologii osobom $\mathrm{z}$ niepełnosprawnościami. Nowe technologie są jednym z wielu czynników wpływających na zmianę rządzenia i nowy sposób myślenia. Internet stał się jednym z głównych środków dostępu do informacji, jak i możliwości korzystania z usług. Możliwość wykorzystania nowych technologii w relacjach na przykład organ administracji publicznej - interesant $z$ jednej strony stwarza oczywiście szansę na ich usprawnienie oraz przyspieszenie, ale z drugiej niesie ze sobą ryzyko wykluczenia istotnej części społeczeństwa ${ }^{11}$. Nie można zapominać, że nie wszyscy potrafią sprawnie poruszać się w nowej rzeczywistości cyfrowej. Są bowiem osoby, które z uwagi na niepełnosprawność mają spore trudności w korzystaniu z możliwości technologicznych. Osoby $\mathrm{z}$ niepełnosprawnościami mogą stanowić zatem grupę społeczną, która dotknięta jest wykluczeniem cyfrowym. Przez pojęcie wykluczenia cyfrowego osób z niepełnosprawnościami rozumie się „ograniczony dostęp lub jego brak do technologii informacyjno-komunikacyjnych, niewynikający ze swobodnego wyboru, ale z ograniczeń związanych z niepełnosprawnością. Dotyczy zatem tych osób, których niepełnosprawność sensoryczna, motoryczna, intelektualna lub psychiczna powoduje powstanie bariery w dostępie do informacji lub technologii komunikacyjnej"12.

\section{Problem braku zapewnienia dostępności cyfrowej dla osób z niepełnosprawnościami}

Problem z dostępnością cyfrową zwłaszcza dla osób z niepełnosprawnościami dostrzegany jest od kilku lat i w związku z tym podejmowane były różne działania mające na celu pomoc osobom $\mathrm{z}$ niepełnosprawnościami w tej kwestii.

Wymogi dotyczące dostępności do technologii informacyjno-komunikacyjnych zawarte są w Konwencji o prawach osób niepełnosprawnych sporządzo-

11 F. Tereszkiewicz, Dyrektywa Unii Europejskiej w sprawie dostępności stron internetowych i aplikacji mobilnych organów sektora publicznego:nowe obwiązki dla administracji publicznej w Polsce, „Przegląd Nauk Stosowanych" 2016 r., nr 11, s. 65.

12 J. Zadrożny, Cyfrowe włączenie osób z niepełnosprawnościami, [w:] Najważniejsze wyzwania po ratyfikacji przez Polskę Konwencji ONZ o Prawach Osób Niepełnosprawnych, „Biuletyn Rzecznika Praw Obywatelskich” 2012, nr 10, s. 42. 
nej w Nowym Jorku dnia 13 grudnia 2006 r. (dalej: Konwencja), którą Polska ratyfikowała 6 października 2012 r. ${ }^{13}$ Konwencja stanowi swoistą konstytucję dla osób z niepełnosprawnościami. Kofi Annan, były sekretarz generalny ONZ, w dniu jej uchwalenia powiedział, iż stanowi ona „obietnicę nowej ery” i „historyczne osiągnięcie dla 650 milionów osób niepełnosprawnych na całym świecie" 14 . Kluczowe znaczenie dla omawianej kwestii dostępności cyfrowej (to jest dostępności do informacji i technologii) wykazuje art. 9 Konwencji, w którym prawodawca narzuca na organy państwowe i samorządowe przygotowanie rozwiązań, które spełniłyby wymagania dostępności m.in. do technologii informacyjno-komunikacyjnych, w tym do Internetu, dla osób o różnych potrzebach funkcjonalnych. Należy wyraźnie podkreślić, iż na gruncie Konwencji ustawodawca traktuje dostępność informacji i technologii na równi z dostępnością architektoniczną czy transportową ${ }^{15}$. Równie istotna jest regulacja art. 21 Konwencji, która nakłada na państwa-strony obowiązek dostarczania osobom niepełnosprawnym informacji w dostępnych dla nich formach i technologiach, zapewnienie prawa do komunikowania się z urzędami w wybranej formie, nakłanianie instytucji prywatnych, które świadczą usługi dla ogółu społeczeństwa, w tym przez Internet, do dostarczania informacji i usług w formie dostępnej i użytecznej dla osób z niepełnosprawnościami, jak również zachęcania środków masowego przekazu, w tym dostawców informacji przy pomocy sieci Internet, do udostępnienia ich usług osobom z niepełnosprawnościami.

W związku z deficytem dostępności cyfrowej dla osób z niepełnosprawnościami organy europejskie wydawały różnego rodzaju zalecenia bądź rezolucje, mające na celu rozpowszechnianie dostępności (np. zalecenie Rady Europy nr Re$c(2006) 5^{16}$, zalecenie nr Rec(2009) $8^{17}$, Europejska agenda cyfrowa ${ }^{18}$ bądź Rezolucja $\left.\operatorname{ResAP}(2001) 3^{19}\right)$. W celu rozpoznania istniejących problemów i potrzeb przeprowadzono wiele konsultacji społecznych i analiz dotyczących państw członkow-

13 Dz.U. z 2012 r. poz. 1169.

14 K. Mrugalska, Wstęp, [w:], Polska droga do Konwencji o prawach osób niepełnosprawnych ONZ, red. A.M. Waszkielewicz, Kraków 2008, s. 6.

15 J. Zadrożny, Cyfrowe włączenie..., s. 43.

16 Zalecenie nr Rec(2006)5 Komitetu Ministrów dla państw członkowskich Plan działań Rady Europy w celu promocji praw i pełnego uczestnictwa osób niepełnosprawnych w społeczeństwie: podnoszenie jakości życia osób niepełnosprawnych w Europie 2006-2015 zostało przyjęte przez Komitet Ministrów w dniu 5 kwietnia 2006 r. podczas 961 posiedzenia zastępców ministrów.

17 Zalecenie nr Rec(2009)8 Komitetu Ministrów Rady Europy dla państw członkowskich o osiągnięciu pełnej integracji przez zastosowanie zasad projektowania uniwersalnego, przyjęte przez Komitet Ministrów dnia 21 października 2009 r. na 1068 posiedzeniu przedstawicieli ministrów.

18 Komunikat Komisji do Parlamentu Europejskiego, Rady, Europejskiego Komitetu Ekonomiczno-Społecznego i Komitetu Regionów: Europejska agenda cyfrowa, Bruksela, dnia 26 sierpnia 2010, KOM(2010) 245.

19 Rezolucja ResAP(2001)3 w sprawie dążenia do pełnego obywatelstwa osób niepełnosprawnych poprzez nowe technologie sprzyjające włączeniu społecznemu, przyjęte przez Komitet Ministrów w dniu 24 października 2001 r. podczas 770 posiedzenia zastępców ministrów. 
Wybrane środki służące zapewnieniu dostępności cyfrowej...

skich, branży i społeczeństwa obywatelskiego, zwłaszcza wśród organizacji działających na rzecz osób z niepełnosprawnościami (np. analiza porównawcza 2010-2011 „Monitorowanie eDostępności”, analiza „Ocena ekonomiczna dla potrzeb poprawy poziomu usług i produktów eDostępności”, konsultacja społeczna za pośrednictwem interaktywnej platformy internetowej Komisji Europejskiej „Twój głos w Europie” (2008), badanie „Dostępność sieci w krajach europejskich”, analiza porównawcza „Ocena postępów eDostępności w Europie” (2006-2008). Powołano również grupę ekspertów państw członkowskich do spraw „e-Integracji” i „komunikacji integracyjnej”, jak również przeprowadzono bezpośrednie konsultacje i spotkania z przedstawicielami głównych organizacji społeczeństwa obywatelskiego, jak Europejskiego Forum Osób Niepełnosprawnych i Europejskiej Unii Niewidomych oraz branży oprogramowania.

$\mathrm{Na}$ gruncie regulacji polskich drgnęło w omawianym zakresie w 2005 r., kiedy to nowelizacja ustawy z dnia 17 lutego 2005 r. o informatyzacji działalności podmiotów realizujących zadania publiczne ${ }^{20}$ m.in. określiła zasady dostosowania systemów teleinformatycznych używanych do realizacji zadań publicznych do minimalnych wymagań dla systemów teleinformatycznych używanych do realizacji tych zadań. Z kolei w 2012 r. wydane zostało rozporządzenie wykonawcze ${ }^{21}$ do ww. ustawy o informatyzacji działalności podmiotów realizujących zadania publiczne, w którym ustawodawca wskazał, iż „w systemie teleinformatycznym podmiotu realizującego zadania publiczne służące prezentacji zasobów informacji należy zapewnić spełnienie przez ten system wymagań Web Content Accessibility Guidelines (WCAG 2.0), z uwzględnieniem poziomu AA", które zostały określone w załączniku do rozporządzenia ( $\$ 19$ rozporządzenia). Z kolei w 2014 r. zostało przygotowane rozporządzenie Ministra Administracji i Cyfryzacji w sprawie szczegółowych wymagań dotyczących świadczenia udogodnień dla osób niepełnosprawnych przez dostawców publicznie dostępnych usług telefonicznych ${ }^{22}$, na podstawie którego dostawca taki zobowiązany został do dostosowania swoich strony internetowej i udostępnienia za jej pośrednictwem informacji do wymagań WCAG 2.0. Niestety, nadal nie było mowy o dostępności aplikacji mobilnych administracji publicznej ${ }^{23}$, a kwestia stron internetowych była poruszona jedynie fragmentarycznie; dodatko-

20 Dz.U. z 2017 r. poz. 570 z późn. zm; dalej: ustawa o informatyzacji działalności podmiotów realizujących zadania publiczne.

21 Rozporządzenie Rady Ministrów z dnia 12 kwietnia 2012 r. w sprawie Krajowych Ram Interoperacyjności, minimalnych wymagań dla rejestrów publicznych i wymiany informacji w postaci elektronicznej oraz minimalnych wymagań dla systemów teleinformatycznych (Dz.U. z 2012 r. poz. 526 z późn. zm.); dalej: rozporządzenie w sprawie Krajowych Ram Interoperacyjności.

Rozporządzenie Ministra Administracji i Cyfryzacji z dnia 26 marca 2014 r. w sprawie szczegółowych wymagań dotyczących świadczenia udogodnień dla osób niepełnosprawnych przez dostawców publicznie dostępnych usług telefonicznych (Dz.U. z 2014 r. poz. 464). 
wo - jak pokazywały kontrole ${ }^{24}$ - większość stron internetowych instytucji publicznych była niedostosowana do wymagań WCAG 2.0.

Z kolei na gruncie europejskim w 2012 r. Komisja Europejska postanowiła zharmonizować ten obszar w ramach całej Unii. Do osiągnięć ustawodawcy w tym zakresie należy przyjęta, przez Parlament Europejski po 4 latach prac, 26 października 2016 r., dyrektywa 2016/2012 w sprawie dostępności stron internetowych i mobilnych aplikacji organów sektora publicznego ${ }^{25}$ (dalej: dyrektywa o dostępności). Zasadniczym celem dyrektyw o dostępności było zharmonizowanie regulacji państw członkowskich w zakresie dostępności stron internetowych i aplikacji mobilnych ${ }^{26}$ wszystkich organów sektora publicznego (urzędów, policji, sądów, państwowych bibliotek, szpitali, uczelni ${ }^{27}$, z nielicznymi wyjątkami podmiotowymi ${ }^{28}$ i przedmiotowymi ${ }^{29}$. W dyrektywie o dostępności określono minimalne wymogi dostępności stron internetowych i aplikacji mobilnych organów sektora publicznego które mają być „bardziej postrzegalne, funkcjonalne, zrozumiałe i rzetelne”. Są to tzw. cztery zasady dostępności ${ }^{30}$. Włączono również zestaw przepisów umożliwiających organom sektora publicznego stosowanie wymogów dostępności w takim wymiarze, aby nie stanowiły one nieproporcjonalnego obciążenia (z uwzględnieniem czynników takich jak wielkość i zasoby organu sektora publicznego) ${ }^{31}$. Ponadto ustanowiono również wymogi dotyczące skutecznego postępowania egzekucyjnego (w tym możliwość zwrócenia się do rzecznika praw obywatelskich), nałożono na państwa członkowskie obowiązek systematycznego monitorowania dostępności stron i aplikacji sektora publicznego, państwa członkowskie zobligowano także do przedstawiania Komisji Europejskiej sprawozdania na temat wyników monitorowania (co 3 lata). Dyrektywa o dostępności odnosi się do standardów zapewniają-

NIK sprawdziła wypełnianie 34 z 36 wymaganych zaleceń standardu WCAG 2.0 w 23 serwisach internetowych instytucji publicznych, zwracając uwagę zwłaszcza na serwisy urzędów publicznych, z których korzystają osoby z niepełnosprawnościami. Zdaniem NIK urzędy nie zapewniły wymaganej dostępności ich serwisów dla osób z niepełnosprawnościami. Odpowiednio dostosowane były tylko 2 z 23 badanych serwisów internetowych (Ministerstwa Zdrowia i PFRON-u). Na pozostałych 21 stronach WWW NIK stwierdziła istotne błędy, przy czym w 3 wypadkach strony oceniono negatywnie; zob. NIK o dostosowaniu stron internetowych do potrzeb osób z niepełnosprawnościami, NIK, 10.02.2016, https://www.nik.gov.pl/aktualnosci/nik-o-dostosowaniu-stron-internetowych-do-potrzeb-osob-z-niepelnosprawnosciami.html [dostęp: 2.07.2019]. Dz.Urz. UE L 327 z 2.12.2016, s. 1.

263 grudnia 2012 r. Komisja Europejska, która odegrała wiodącą rolę w procesie formalizacji dyrektywy (była pierwszym ogniwem tego procesu), jako dysponent konstytutywny przedłożyła wniosek dotyczący dyrektywy w sprawie dostępności stron internetowych instytucji sektora publicznego, przyjmując za podstawę prawną art. 114 Traktatu FUE /dokument COM(2012) 721 final - 2012/0340 (COD). Wniosek ten obejmował tylko 12 rodzajów stron internetowych sektora publicznego, pozostawiając państwom członkowskim swobodę w zakresie rozszerzenia tego wykazu. Nie obejmował swoim zakresem aplikacji mobilnych. Ostatecznie dyrektywa dotyczy wszystkich publicznych stron WWW (nie tylko 12, jak było w projekcie) oraz aplikacji mobilnych. F. Tereszkiewicz, Dyrektywa Unii Europejskiej..., s. 65.

28 Np. art. 1 ust. 3, art. 5, art. 1 pkt 5 dyrektywy o dostępności.

$29 \quad$ Np. art. 1 ust. 4 dyrektywy o dostępności.

30 Artykuł 4 dyrektywy o dostępności.

31 Artykuł 5 dyrektywy o dostępności. 
Wybrane środki służące zapewnieniu dostępności cyfrowej...

cych większą dostępność stron internetowych i aplikacji. Takie standardy przewidują na przykład konieczność umożliwienia przeglądania stron bez konieczności posługiwania się myszką, ponieważ często czynność ta sprawia trudności osobom niepełnosprawnym.

Dyrektywa o dostępności miała kluczowe znaczenie dla zapewnienia pełnej integracji w społeczeństwie cyfrowym wszystkich obywateli, w szczególności osób z niepełnosprawnościami. Przyjęcie dyrektywy to milowy krok do osiągnięcia integracyjnego społeczeństwa cyfrowego, w którym bezpośredni beneficjenci, czyli osoby z niepełnosprawnościami, będą mieli dostęp do usług internetowych i informacji na równi z innymi ludźmi. Wskazywano, iż ustanowienie w ramach Unii Europejskiej wspólnych standardów tworzenia stron WWW i aplikacji mobilnych pozwoli w dłuższym okresie obniżyć koszty ich tworzenia. „Kwestia ta była o tyle pilna, że większość państw członkowskich dysponowała już aktami prawnymi dotyczącymi dostępności, jednakże cechowały się one znacznym zróżnicowaniem, jeżeli chodzi o konkretne regulacje i wykorzystywane środki”32. Podnoszono, że jeżeli „Unia Europejska nie podjęłaby w tym zakresie działań harmonizujących, to wraz z upływem czasu narastałyby rozbieżności pomiędzy regulacjami obowiązującymi w poszczególnych państwach członkowskich, a koszty ich zredukowania stawałyby się coraz większe"33. Harmonizacja środków krajowych dotyczących sektora publicznego na poziomie unijnym była proponowana jako warunek konieczny zakończenia takiego rozdrobnienia i braku zaufania na rynku usług dostępności sieci.

\section{Obecna sytuacja osób z niepełnosprawności w Polsce w zakresie dostępności cyfrowej}

Rzeczywistym celem dyrektywy o dostępności była konieczność transpozycji jej postanowień do krajowych regulacji prawnych państw członkowskich. Co zatem dyrektywa ta oznaczała dla Polski? Wejście jej w życie wiązało się z koniecznością albo przyjęcia w polskim porządku prawnym nowego aktu prawnego, albo gruntownego znowelizowania aktów wówczas obowiązujących, jakimi były ustawa o informatyzacji działalności podmiotów realizujących zadania publiczne czy rozporządzenie w sprawie Krajowych Ram Interoperacyjności, które zgodnie z tym zostało powyżej powiedziane w niewielkim stopniu odnosiło się bezpośrednio do osób z niepełnosprawnościami, stanowiąc jedynie, że w systemach teleinformatycznych podmiotów realizujących zadania publiczne należy zapewnić spełnienie przez ten system wskazanych wymagań.

$\begin{array}{ll}32 & \text { F. Tereszkiewicz, Dyrektywa Unii Europejskiej..., s. } 65 . \\ 33 & \text { Ibidem. }\end{array}$ 
W kontekście dyrektywy o dostępności polski ustawodawca stanął przed obowiązkiem m.in. wdrożenia oświadczenia o dostępności, opracowania procedury zgłaszania skarg na brak dostępności, wybrania instytucji, która będzie odpowiedzialna za monitoring i sprawozdawczość, promocji i ułatwiania organizacji szkoleń dotyczących dostępności oraz stworzenia skutecznego postępowania wykonawczego, które obejmowałoby zwłaszcza możliwość nawiązania kontaktu z rzecznikiem praw obywatelskich.

W celu wdrożenia do polskiego porządku prawnego postanowień ww. dyrektywy o dostępności ustawodawca przyjął najpierw projekt ustawy z dnia 23 listopada 2018 r. o dostępności cyfrowej stron internetowych i aplikacji mobilnych podmiotów publicznych, a 4 kwietnia 2019 r. parlament na posiedzeniu nr 79 uchwalił ustawę o dostępności cyfrowej stron internetowych i aplikacji mobilnych podmiotów publicznych (dalej: ustawa o dostępności cyfrowej, u.d.c.) ${ }^{34}$, która weszła w życie 23 maja 2019 r. ${ }^{35}$ Ustawa o dostępności cyfrowej wpisuje się w założenia przyjętego 17 lipca 2018 r. rządowego Programu Dostępność Plus, którego głównym celem jest podniesienie jakości życia obywateli, którzy ze względu na stan zdrowia, wiek czy niepełnosprawność napotykają na ograniczenia mobilności i percepcji w życiu codziennym. Program ten obejmuje swoim zasięgiem również działania w obszarze cyfryzacji ${ }^{36}$. Ustawa o dostępności cyfrowej stanowi innowacyjne na gruncie prawa polskiego rozwiązanie o charakterze systemowym, które określa środki służące zapewnieniu dostępności cyfrowej dla osób niepełnosprawnych. Ustawa ta wyznacza nowe obowiązki co do standardu stron internetowych i aplikacji mobilnych podmiotów publicznych, które mają stać się dostępne także dla osób z niepełnosprawnościami. Ustawa o dostępności cyfrowej określa wymagania dostępności cyfrowej stron WWW i aplikacji mobilnych podmiotów publicznych, wymagania dotyczące treści, przeglądu i aktualizacji deklaracji dostępności stron i aplikacji, zasady monitorowania oraz kompetencje organu właściwego w sprawach monitorowania zapewniania dostępności cyfrowej stron i aplikacji, jak również postępowanie w sprawie zapewniania dostępności cyfrowej omawianych stron i aplikacji ${ }^{37}$.

Ustawę o dostępności cyfrowej stosuje się do posiadających strony internetowe lub aplikacje mobilne jednostek sektora finansów publicznych (dalej: jsfp.), innych

34 Ustawa z dnia 4 kwietnia 2019 r. o dostępności cyfrowej stron internetowych i aplikacji mobilnych podmiotów publicznych (Dz.U. z 2019 r. poz. 848).

35 Artykuły 5-11, art. 12 pkt 2 i 3 oraz art. 13-19 wchodzą w życie w zakresie: 1) stron internetowych podmiotów publicznych nieopublikowanych przed 23 września 2018 r. - z dniem 23 września 2019 r.; 2) stron internetowych podmiotów publicznych opublikowanych przed 23 września 2018 r. - z dniem 23 września 2020 r.; 3) aplikacji mobilnych podmiotów publicznych - z dniem 23 czerwca $2021 \mathrm{r}$.

Zob. Rząd przyjął projekt ustawy o dostępności cyfrowej stron internetowych i aplikacji mobilnych podmiotów publicznych, gov.pl, 19.12.2018, https://www.gov.pl/web/cyfryzacja/rzad-przyjal-projekt-ustawy-o-dostepnosci-cyfrowej-stron-internetowych-i-aplikacji-mobilnych-podmiotow-publicznych [dostęp: 2.07.2019]. 
Wybrane środki służące zapewnieniu dostępności cyfrowej...

niż jsfp., państwowych jednostek organizacyjnych nieposiadających osobowości prawnej, innych niż jsfp. osób prawnych, utworzonych w celu zaspokajania potrzeb o charakterze powszechnym, jeżeli ww. podmioty finansują je w ponad 50\%, posiadają ponad połowę udziałów albo akcji lub sprawują nadzór nad organem zarządzającym, lub mają prawo do powoływania ponad połowy składu organu nadzorczego lub zarządzającego. Najważniejsza z przyjętych przez Sejm poprawek Senatu do projektu ustawy o dostępności cyfrowej rozszerzyła obowiązek dostosowania stron internetowych i aplikacji mobilnych przez związki ww. podmiotów publicznych. W trakcie prac nad komentowaną ustawą niektóre organizacje pozarządowe podnosiły, że stawia ona nadmierne wymagania organizacjom, które nie mają środków na realizację zaleceń. W efekcie wyłączono spod jej obowiązków małe, lokalne organizacje, których zadaniem publicznym nie jest prowadzenie działalności na rzecz osób niepełnosprawnych lub osób starszych, jeśli wdrożenie nowych standardów wiązałoby się dla nich $\mathrm{z}$ nadmiernymi kosztami i obciążeniami organizacyjnymi ${ }^{38}$. Wszystkie wymienione podmioty określa ustawodawca mianem „podmiotów publicznych”. Jak wynika z powyższego, zakres podmiotowy ustawy jest dość szeroki, a jego uzasadnieniem była konieczność wdrożenia przepisów dyrektywy o dostępności, która w zakresie pojęcia „organu sektora publicznego” ujmuje również „podmiot prawa publicznego"39.

Poprzez regulacje ustawy o dostępności cyfrowej ustawodawca podniósł trudny problem praktyczny, sformułował jednoznaczne cele i rozwiązania w postaci środków/instrumentów prawnych, służących zapewnieniu dostępności cyfrowej w celu przełamywania barier, z jakimi borykają się osoby z niepełnosprawnościami w różnych sferach życia. Stanowi to istotne novum, gdyż tego rodzaju rozwiązania $\mathrm{w}$ ówczesnym stanie prawnym nie funkcjonowały.

Podstawowy środek zmierzający do przełamania bariery dostępności cyfrowej dla osób z niepełnosprawnościami stanowi tzw. jednolity standard, do wdrożenia którego zobowiązano wyżej wymienione podmioty publiczne. Ustawodawca nakazuje zwiększenie dostępności cyfrowej stron internetowych i aplikacji mobilnych w oparciu o wspólne wymogi dostępności dla osób z ograniczeniami funkcjonalnymi, m.in. osób niewidomych i słabowidzących, osób głuchych i słabosłyszących, osób mających trudności w komunikowaniu się z otoczeniem, jak również osób starszych. Podmioty publiczne zapewniają dostępność cyfrową, która polega na zapewnieniu funkcjonalności, kompatybilności, postrzegalności i zrozumiałości stron WWW oraz aplikacji mobilnych. Cechy te ustawodawca definiuje w słowniczku do ustawy o dostępności cyfrowej, jak również specyfikuje w załączniku nr 1

38 Artykuł 8 ust. 1 u.d.c.

39 Zob. Uzasadnienie do projektu ustawy o dostępności cyfrowej stron internetowych i aplikacji mobilnych podmiotów publicznych, Sejm Rzeczpospolitej Polskiej, 18.02.2019, https://www.sejm.gov.pl/sejm8.nsf/druk. xsp?nr=3119 [dostęp: 2.07.2019]. 
do przedmiotowej ustawy. Funkcjonalność oznacza właściwość strony internetowej lub aplikacji mobilnej, która umożliwia użytkownikowi skorzystanie ze wszystkich oferowanych przez nie funkcji ${ }^{40}$, np. wystarczającej ilości czasu, dostępności z klawiatury, możliwości nawigacji, co doprecyzowuje ustawodawca w załączniku nr 1 ustawy o dostępności cyfrowej. Kompatybilność to $\mathrm{z}$ kolei właściwość strony WWW lub aplikacji mobilnej, umożliwiająca tej stronie lub aplikacji współpracę z możliwie największą liczbą programów, w tym z narzędziami i programami wspomagającymi osoby niepełnosprawne ${ }^{41}$. Kolejna cecha, jaką jest postrzegalność, oznacza taką właściwość strony lub aplikacji, która umożliwia jej odbiór przez użytkownika za pomocą zmysłu słuchu, wzroku lub dotyku, np. alternatywa w postaci tekstu, możliwość adaptacji, odpowiednia (zrozumiała) prezentacja zawartości (orientacja - wyświetlanie treści w układzie poziomym, jak i pionowym), tylko audio oraz tylko wideo (nagranie), napisy rozszerzone (nagranie), audiodeskrypcja (nagranie), ułatwienie percepcji treści (np. użycie koloru, kontrast, zmiana rozmiaru tekstu, tekst w postaci grafiki, odstępy w tekście $)^{42}$. I ostatnia cecha, jaką musi posiadać strona WWW lub aplikacja mobilna podmiotów publicznych, to ich zrozumiałość, która pozwoli użytkownikowi tych stron i aplikacji zrozumienie treści oraz sposobu ich prezentacji (to jest np. możliwość odczytania, pomoc przy wprowadzaniu informacji $)^{43}$.

W art. 8 ust. 2 u.s.c. ustawodawca wskazuje elementy, które zawsze muszą być dostępne cyfrowo dla użytkownika. Wymienia wśród nich strony podmiotowe Biuletynu Informacji Publicznej (dalej: BIP), jak również elementy i funkcje strony internetowej lub aplikacji mobilnej, takie jak dane teleadresowe podmiotu publicznego oraz link do strony podmiotowej BIP podmiotu publicznego, narzędzia służące do kontaktu z podmiotem publicznym, deklarację dostępności strony internetowej lub aplikacji mobilnej podmiotu publicznego (o której będzie mowa poniżej), informacje dotyczące sytuacji kryzysowej oraz dokumenty urzędowe, wzory umów, formularze. Zdefiniowanie minimum elementów dostępnych cyfrowo wydaje się niezbędne w kontekście Programu Dostępność Plus ${ }^{44}$, o którym była mowa powyżej.

Jednym ze środków mających na celu zapewnienie dostępności cyfrowej osobom $\mathrm{z}$ niepełnosprawnościami jest zasada alternatywnego dostępu. Ustawodawca zobowiązał podmioty publiczne do zapewnienia alternatywnych sposobów przekazania informacji w każdym przypadku, gdy nie mogą być one dostępne cyfrowo ${ }^{45}$, dlatego w sprawie niedostępnych plików obywatel będzie miał prawo zadzwonić,

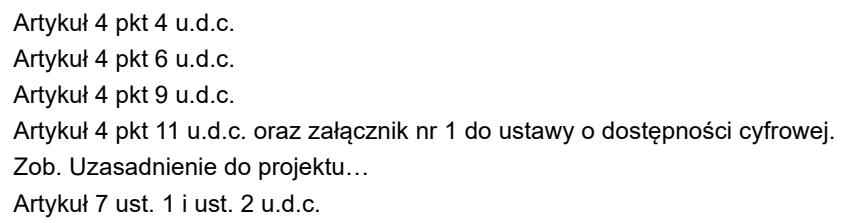


Wybrane środki służące zapewnieniu dostępności cyfrowej...

wysłać email lub poprosić o jego przeczytanie. Jednak szczególny nacisk położono na to, by w pierwszej kolejności podmiot publiczny spowodował dostępność cyfrową niedostępnych treści, a dopiero dalej stosował alternatywne sposoby dostępu do informacji. Warunkiem skorzystania z możliwości niezapewnienia dostępności cyfrowej strony internetowej lub aplikacji mobilnej będzie jednak wcześniejsze przeprowadzenie przez podmiot publiczny i opublikowanie w deklaracji dostępności oceny zapewnienia dostępności cyfrowej strony internetowej lub aplikacji mobilnej, która powinna objąć m.in. takie elementy, jak: oszacowanie kosztów niezbędnych do zapewnienia dostępności cyfrowej, liczbę użytkowników danej strony internetowej lub aplikacji mobilnej oraz wskazanie okresu funkcjonowania danej strony internetowej lub aplikacji mobilnej wraz z częstotliwością publikacji w nich nowych treści ${ }^{46}$.

Kolejny środek służący zapewnieniu dostępności dla osób z niepełnosprawnościami przejawia się w konieczności stworzenia przestrzeni dla autorefleksji, co ma być realizowane przy pomocy tzw. deklaracji dostępności ${ }^{47}$. Jest to dokument, który będzie wymagał od podmiotu publicznego sprawdzenia dostępności cyfrowej swojej strony WWW lub aplikacji mobilnej, jak również stałego nadzoru nad tą dostępnością. Równocześnie deklaracja dostępności stanowi istotne narzędzie informujące osoby niepełnosprawne o tym, czego mogą oczekiwać, korzystając z danej strony internetowej lub aplikacji mobilnej ${ }^{48}$. Deklarację dostępności sporządza się z wykorzystaniem wzoru wskazanego w załączniku do decyzji wykonawczej Komisji Europejskiej (UE) 2018/1523 z dnia 11 października 2018 r. ustanawiającej wzór oświadczenia w sprawie dostępności zgodnie z dyrektywą Parlamentu Europejskiego i Rady (UE) 2016/2102 w sprawie dostępności stron internetowych i mobilnych aplikacji organów sektora publicznego ${ }^{49}$. Deklaracja dostępności zawiera nazwę podmiotu publicznego, wskazuje stronę internetową lub aplikację mobilną, do której odnosi się przedmiotowa deklaracja, określa poziom dostępności (z podziałem na pełną i częściową dostępność, a także niedostępność), wskazuje treści niedostępne, zawiera pouczenie o możliwości złożenia skargi oraz wskazuje organy właściwe do jej rozpatrzenia. Są to elementy wymienione w sekcji 1 załącznika do decyzji wykonawczej 2018/1523 ${ }^{50}$. Ponadto, zgodnie z art. 10 ust. 4 u.d.c., deklaracja dostępności zawiera datę publikacji strony WWW lub aplikacji mobilnej, datę ich ostatniej aktualizacji, informację lub link do informacji o sposobie dokonania oceny dostępności cyfrowej, a także informacje na temat utworzonych na stro-

46 Ocena skutków regulacji zawartych w rządowym projekcie ustawy o dostępności cyfrowej stron internetowych i aplikacji mobilnych podmiotów publicznych (druk sejmowy nr 3119), Biuro Analiz Sejmowych Kancelarii Sejmu, Warszawa, 16 stycznia 2019 r., s. 4-5.

47 Artykuł 10 ust. 1 u.d.c oraz Rząd przyjął projekt...

48 Ocena skutków regulacji..., s. 4.

49 Zwana „decyzją wykonawczą 2018/1523”. Artykuł 10 ust. 2 u.d.c.

50 Artykuł 10 ust. 3 u.d.c. 
nie lub w aplikacji mobilnej skrótów klawiszowych, służących przemieszczaniu się po elementach strony lub aplikacji i uruchamianiu dostępnych na nich funkcji. Deklaracja musi zawierać również dane teleadresowe siedziby podmiotu publicznego oraz dane kontaktowe osób właściwych w sprawach dostępności cyfrowej w podmiocie publicznym. Nie oznacza to konieczności tworzenia nowych miejsc pracy, wymaga jednak powierzenia jednemu z pracowników obowiązku kontaktu z osobami niepełnosprawnymi zgłaszającymi się do urzędu m.in. w kwestiach dostępności cyfrowej. $Z$ deklaracji o dostępności powinna wynikać również informacja o dostępności architektonicznej siedziby podmiotu publicznego dla osób z niepełnosprawnościami. Informacje te mają odnosić się do ewentualnych ułatwień architektonicznych, takich jak podjazdy, platformy schodowe, oznaczenia dla osób niewidomych czy słabowidzących, odpowiednio przygotowane toalety ${ }^{51}$. Deklaracja zawiera też informację o dostępności tłumacza języka migowego, link do deklaracji dostępności aplikacji mobilnej, informację o możliwości powiadomienia podmiotu publicznego o braku dostępności cyfrowej, link do strony internetowej rzecznika praw obywatelskich oraz, według ust. 5 art. 10 u.d.c., adres elektroniczny, pod którym możliwe jest pobranie i zainstalowanie danej aplikacji mobilnej. Ustawodawca na gruncie ustawy o dostępności cyfrowej ${ }^{52}$ określa również miejsca publikacji deklaracji dostępności. Jest to ważne zwłaszcza dla deklaracji dostępności aplikacji mobilnych, gdyż powinna ona znaleźć się na wybranej spośród posiadanych przez podmiot publiczny stron internetowych (w sytuacji deklaracji dostępności strony WWW wiadomo, że musi się ona znaleźć na tej samej stronie internetowej) ${ }^{53}$. Dodatkowo ustawodawca nakazuje regularny, coroczny (do 31 marca każdego roku) przegląd informacji zawartych $\mathrm{w}$ deklaracjach dostępności, zobowiązując podmiot publiczny do jej aktualizacji niezwłocznie również w sytuacji, gdy strona WWW lub aplikacja mobilna została poddana zmianom, które mieć wpływ na jej dostępność cyfrową ${ }^{54}$.

Innym środkiem zapewniającym dostępność cyfrową osobom z niepełnosprawnościami jest możliwość żądania zapewnienia dostępności cyfrowej, z której może skorzystać każdy zainteresowany użytkownik - bez względu na jego interes prawny lub faktyczny ${ }^{55}$. Zainteresowany może poinformować podmiot publiczny o braku dostępności cyfrowej strony internetowej czy aplikacji mobilnej lub ich elementów bądź żądać zapewnienia dostępności cyfrowej za pomocą alternatywnego sposobu dostępu ${ }^{56}$. Jak wskazano w uzasadnieniu do projektu ustawy

\footnotetext{
Uzasadnienie do projektu...

Artykuł 10 ust. 7 u.d.c.

Uzasadnienie do projektu...

Art. 11 u.d.c.

Zob. Rząd przyjął projekt...

Artykuł 18 ust. 1 u.d.c.
} 
Wybrane środki służące zapewnieniu dostępności cyfrowej...

o dostępności cyfrowej stron internetowych i aplikacji mobilnych podmiotów publicznych, dzięki przyznanemu uprawnieniu użytkownicy stron WWW i aplikacji mobilnych zostali włączeni w tworzenie i nadzorowanie dostępności cyfrowej ${ }^{57}$. Omawiane żądanie powinno zawierać dane kontaktowe osoby występującej z żądaniem, wskazanie strony lub aplikacji bądź ich elementu, które mają być dostępne cyfrowo, wskazanie sposobu kontaktu z osobą występującą z żądaniem, jak również wskazanie alternatywnego sposobu dostępu (jeżeli dotyczy) ${ }^{58}$. Zapewnienie takiej dostępności powinno nastąpić ze strony podmiotu publicznego bez zbędnej zwłoki, jednak nie później niż w terminie 7 dni od dnia wystąpienia z żądaniem przez zainteresowanego ${ }^{59}$. Jeśli podmiot publiczny nie jest w stanie zapewnić dostępności cyfrowej wskazanego elementu w ww. ustawowym terminie, powiadamia zgłaszającego żądanie o przyczynach opóźnienia oraz o terminie, w którym zapewni dostępność wskazanego elementu. Termin ten nie powinien być jednak dłuższy niż 2 miesiące od dnia zgłoszenia żądania ${ }^{60}$. Ustawodawca przewidział jednak na gruncie ustawy o dostępności cyfrowej możliwość odmowy przez podmiot publiczny zapewnienia dostępności cyfrowej elementu strony WWW lub aplikacji mobilnej, jeżeli wiązałoby się to z ryzykiem naruszenia integralności lub wiarygodności przekazywanych informacji ${ }^{61}$.

W ścisłym związku z powyższym środkiem służącym zapewnieniu dostępności cyfrowej osobom z niepełnosprawnościami wiąże się prawo złożenia skargi na brak dostępności ${ }^{62}$. Prawo takie przysługuje w przypadku odmowy zapewnienia dostępności cyfrowej strony WWW lub aplikacji mobilnej lub ich elementu bądź w przypadku odmowy skorzystania $\mathrm{z}$ alternatywnego sposobu dostępu przez osobę występującą $\mathrm{z}$ żądaniem ${ }^{63}$. Do skarg rozpatrywanych w postępowaniach o sprawie zapewnienia dostępności cyfrowej strony internetowej, aplikacji mobilnej lub ich elementów stosuje się przepisy Kodeksu postępowania administracyjnego ${ }^{64}$.

Wymóg zapewnienia dostępności cyfrowej dla osób z niepełnosprawnościami jest wzmocniony poprzez możliwość nałożenia kary na podmiot, który nie spełni tego wymagania. Kwestie nakładania kar pieniężnych reguluje art. 19 u.d.c., który wskazuje dwie granice wysokości kar, to jest do 10 tys. i do 5 tys. zł. Podmiot publiczny, który w sposób nieuzasadniony i uporczywy nie zapewnia dostępności cyfrowej strony internetowej lub aplikacji mobilnej, podlega karze do 10 tys. zł.

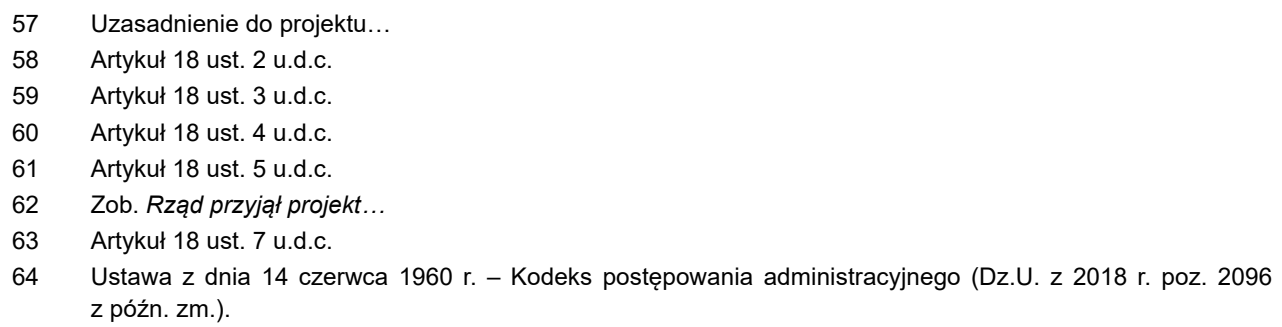


Ustawodawca równocześnie tłumaczy, co oznacza pojęcie „uporczywego niewywiązywania się z zapewnienia jakości stron WWW lub aplikacji mobilnych", wskazując w art. 19 ust. 2 u.d.c., iż działanie takie cechuje brak poprawy dostępności cyfrowej $\mathrm{w}$ trzech kolejnych monitorowaniach. Z kolei podmiot publiczny, który nie sporządza i nie publikuje deklaracji dostępności albo nie zawiera w deklaracji dostępności wymaganych ustawą o dostępności cyfrowej elementów (w dwóch kolejnych monitorowaniach) bądź nie zapewnia dostępności cyfrowej strony podmiotowej BIP (w dwóch kolejnych monitorowaniach), podlega karze w wysokości do 5 tys. zł.

\section{Podsumowanie}

Niepełnosprawność dotyczy całej ludzkości - niezależnie od kraju pochodzenia, pozycji społecznej czy statusu materialnego. Człowiek na swojej drodze życiowej staje w obliczu różnych sytuacji, których nie jest w stanie przewidzieć, i w każdej chwili może doświadczyć pogorszenia stanu zdrowia, a przez to stać się osobą z niepełnosprawnością ${ }^{65}$. Izolacja społeczna, wykluczenie i dyskryminacja osób $\mathrm{z}$ niepełnosprawnościami pozostaje problemem polskiego społeczeństwa. Dzieje się tak pomimo podejmowanych od lat środków służących przełamywaniu barier lub zmniejszaniu przeszkód uniemożliwiających osobom z niepełnosprawnościami udział w życiu społecznym i publicznym.

Od kilkudziesięciu lat jesteśmy świadkami intensywnego rozwoju technologii, które coraz mocniej wkraczają w nasze życie i częstokroć je ułatwiają. Nowe technologie cyfrowe mogą spełniać niebagatelne funkcje również w życiu codziennym osób z niepełnosprawnościami, a niestety zauważamy, iż dotychczas nie były one udostępniane osobom z niepełnosprawnościami w sposób wystarczający, to znaczy tak, aby mogły one w naturalny sposób otwierać możliwości rozwoju autonomii. Zarówno organizacje pozarządowe, jak i urzędy administracji publicznej stanowią podmioty, które dysponują istotnymi zasobami informacyjnymi i możliwościami komunikacyjnymi. Jednakże często podmioty te nie potrafiły zapewnić dostępności do nich osobom $\mathrm{z}$ niepełnosprawnościami ${ }^{66}$, w momencie gdy dostępność cyfrowa jest jednym $\mathrm{z}$ fundamentalnych warunków równego i aktywnego uczestnictwa osób $\mathrm{z}$ niepełnosprawnościami $\mathrm{w}$ społeczeństwie.

W praktyce wyróżnia się kilka rodzajów ograniczeń dostępności cyfrowej. Są to ograniczenia funkcjonalne, dotyczące zwłaszcza osób z niepełnosprawnościami,

Osoba niepełnosprawna aktywnym uczestnikiem życia społecznego i zawodowego, Projekt współfinansowany ze środków Unii Europejskiej w ramach europejskiego funduszu społecznego, Rzeszów 2014, http://www. rops.rzeszow.pl/dokumenty/badania/5_niepelnosprawni.pdf [dostęp: 2.07 2019].

66 J. Królewski et al., Potencjał Internetu i jego (nie)wykorzystanie w kontekście potrzeb osób niepełnosprawnych, [w:] Polacy niepełnosprawni. Od kompleksowej diagnozy do modelu polityki społecznej, red. B.Gąciarz, S. Rudnicki, Kraków 2014, s. 362. 
Wybrane środki służące zapewnieniu dostępności cyfrowej...

poznawcze, motoryczne lub zmysłowe. $Z$ tego powodu istotna jest kwestia intuicyjnej nawigacji w obrębie stron WWW lub aplikacji mobilnych, która poprawia komunikację z użytkownikiem oraz ułatwia wyszukiwanie i pozyskiwanie danych. Ważne jest, aby osoby z niepełnosprawnościami mogły korzystać ze stron WWW lub aplikacji mobilnych zwłaszcza podmiotów publicznych, które są skonstruowane zgodnie z zasadami dostępności ${ }^{67}$.

Na kanwie powyższych rozważań należy wyrazić nadzieję, iż rozwiązania przyjęte w ustawie o dostępności cyfrowej - które wynikają zwłaszcza z wniosków wyciągniętych $\mathrm{z}$ obserwacji sytuacji osób z niepełnosprawnościami w Polsce i porównań z doświadczeniami zagranicznymi - będą stanowić jeden z najistotniejszych filarów wsparcia tej grupy osób. Należy zauważyć, iż dla coraz większej liczby obywateli informacje przekazywane za pośrednictwem Internetu, również te o charakterze lokalnym, stanowią główne narzędzie umożliwiające kontakt $\mathrm{z}$ administracją publiczną. Dlatego też dostępność cyfrowa może stać się swoistym medium służącym niwelowaniu społecznej izolacji osób z niepełnosprawnościami.

Na koniec warto przytoczyć słowa Andrusa Ansipa, wiceprzewodniczącego do spraw jednolitego rynku cyfrowego, iż „dostęp do Internetu powinien być dla wszystkich częścią życia codziennego. Wykluczenie milionów Europejczyków nie wchodzi w rachubę”. Z kolei Günther H. Oettinger, komisarz do spraw gospodarki cyfrowej i społeczeństwa cyfrowego, powiedział, że „to niedopuszczalne, by miliony obywateli pozostawały na marginesie społeczeństwa cyfrowego w Europie”. Należy zatem pamiętać, iż efektywne funkcjonowanie w społeczeństwie osób z niepełnosprawnościami stanowi dla nich szansę na rozwój, a w konsekwencji na podwyższenie jakości życia ${ }^{68}$.

\section{Akty prawne}

Konwencja o prawach osób niepełnosprawnych sporządzona w Nowym Jorku dnia 13 grudnia 2006 r. (Dz.U. z 2012 r. poz. 1169).

Decyzja wykonawcza Komisji (UE) 2018/1523 z dnia 11 października 2018 r. ustanawiająca wzór oświadczenia w sprawie dostępności zgodnie z dyrektywą Parlamentu Europejskiego i Rady (UE) 2016/2102 w sprawie dostępności stron internetowych i mobilnych aplikacji organów sektora publicznego.

Dyrektywa Parlamentu Europejskiego i Rady (UE) 2016/2012 z dnia 26 października 2016 r. w sprawie dostępności stron internetowych i mobilnych aplikacji organów sektora publicznego (Dz.Urz. UE L 327 z 2.12.2016, s. 1).

67 J. Królewski et. al., Potencjał Internetu..., s. 361.

68 A.M. Kwiatkowska, B. Rola, Osoba z niepełnosprawnością intelektualną w świecie nowych technologii cyfrowych. Poradnik metodyczny, Polskie Stowarzyszenie na Rzecz Osób z Upośledzeniem Umysłowym, Warszawa 2015, s. 6. 
Konstytucja Rzeczypospolitej Polskiej z dnia 2 kwietnia 1997 r. (Dz.U. z 1997 r. Nr 78, poz. 483 z późn. zm.)

Ustawa z dnia 14 czerwca 1960 r. - Kodeks postępowania administracyjnego (Dz.U. z 2018 r. poz. 2096 z późn. zm.).

Ustawa z dnia 17 lutego 2005 r. o informatyzacji działalności podmiotów realizujących zadania publiczne (Dz.U. z 2017 r. poz. 570 z późn. zm.).

Ustawa z dnia 4 kwietnia 2019 r. o dostępności cyfrowej stron internetowych i aplikacji mobilnych podmiotów publicznych (Dz.U. z 2019 r. poz. 848).

Rozporządzenie Rady Ministrów z dnia 12 kwietnia 2012 r. w sprawie Krajowych Ram Interoperacyjności, minimalnych wymagań dla rejestrów publicznych i wymiany informacji w postaci elektronicznej oraz minimalnych wymagań dla systemów teleinformatycznych (Dz.U. z 2012 r. poz. 526 z późn. zm.).

Rozporządzenie Ministra Administracji i Cyfryzacji z dnia 26 marca 2014 r. w sprawie szczegółowych wymagań dotyczących świadczenia udogodnień dla osób niepełnosprawnych przez dostawców publicznie dostępnych usług telefonicznych (Dz.U. z 2014 r. poz. 464).

Komunikat Komisji do Parlamentu Europejskiego, Rady, Europejskiego Komitetu Ekonomiczno-Społecznego i Komitetu Regionów: Europejska agenda cyfrowa, Bruksela, dnia 26 sierpnia 2010, $\mathrm{KOM}(2010) 245$.

Rezolucja ResAP(2001)3 w sprawie dążenia do pełnego obywatelstwa osób niepełnosprawnych poprzez nowe technologie sprzyjające włączeniu społecznemu, przyjęte przez Komitet Ministrów w dniu 24 października 2001 r. podczas 770 posiedzenia zastępców ministrów.

Zalecenie nr Rec(2006)5 Komitetu Ministrów dla państw członkowskich Plan działań Rady Europy w celu promocji praw i pełnego uczestnictwa osób niepełnosprawnych w społeczeństwie: podnoszenie jakości życia osób niepełnosprawnych w Europie 2006-2015, zostało przyjęte przez Komitet Ministrów w dniu 5 kwietnia 2006 r. podczas 961 posiedzenia zastępców ministrów.

Zalecenie nr Rec(2009)8 Komitetu Ministrów Rady Europy dla państw członkowskich o osiągnięciu pełnej integracji przez zastosowanie zasad projektowania uniwersalnego, przyjęte przez Komitet Ministrów dnia 21 października 2009 r. na 1068 posiedzeniu przedstawicieli ministrów.

\section{Orzecznictwo}

Wyrok TK z dnia 24 października 2001 r., SK 22/01, OTK 2001, nr 7, poz. 216.

\section{Literatura}

Gąciarz B., W kierunku nowego modelu polityki społecznej, [w:] Polacy niepełnosprawni. Od kompleksowej diagnozy do modelu polityki społecznej, red. Barbara Gąciarz, S. Rudnicki, Kraków 2014.

Karaś M., Niepetnosprawność, od spojrzenia medycznego do społecznego i disability studies, „Przegląd Prawny, Ekonomiczny i Społeczny” 2012, nr 4. 
Wybrane środki służące zapewnieniu dostępności cyfrowej...

Konarska J., Bariery aktywności psychospołecznej osób z niepełnosprawnościa - mity i rzeczywistość, „Przegląd Badań Edukacyjnych” 2015, nr 21.

Konstytucja RP. Tom 1. Komentarz art. 1-86, red. M. Safjan, L. Bosek, Warszawa 2016.

Królewski J. et al., Potencjał Internetu i jego (nie)wykorzystanie w kontekście potrzeb osób niepetnosprawnych, [w:] Polacy niepetnosprawni. Od kompleksowej diagnozy do modelu polityki społecznej, red. B. Gąciarz, S. Rudnicki, Kraków 2014.

Kwiatkowska A.M., Rola B., Osoba z niepełnosprawnościq intelektualna $w$ świecie nowych technologii cyfrowych. Poradnik metodyczny, Polskie Stowarzyszenie na Rzecz Osób z Upośledzeniem Umysłowym, Warszawa 2015.

Mrugalska K., Wstęp, [w:], Polska droga do Konwencji o prawach osób niepełnosprawnych ONZ, red. A.M. Waszkielewicz, Kraków 2008.

Raport Polska 2030. Wyzwanie rozwojowe, red. M. Boni, Warszawa 2009.

Tereszkiewicz F., Dyrektywa Unii Europejskiej w sprawie dostępności stron internetowych $i$ aplikacji mobilnych organów sektora publicznego:nowe obwiązki dla administracji publicznej w Polsce, „Przegląd Nauk Stosowanych” 2016, nr 11.

Wysocki M., Projektowanie uniwersalne - równość praw poprzez dostępność, [w:] Najważniejsze wyzwania po ratyfikacji przez Polskę Konwencji ONZ o Prawach Osób Niepetnosprawnych, „Biuletyn Rzecznika Praw Obywatelskich” 2012, nr 10.

Zadrożny J., Cyfrowe włączenie osób z niepetnosprawnościami, [w:] Najważniejsze wyzwania po ratyfikacji przez Polskę Konwencji ONZ o Prawach Osób Niepetnosprawnych, „Biuletyn Rzecznika Praw Obywatelskich” 2012, nr 10.

\section{Źródła internetowe}

https://bip.kprm.gov.pl/kpr/form/r8646930822047,Projekt-ustawy-o-zapewnieniu-dostepnosci-osobom-ze-szczegolnymi-potrzebami-POPRZ.html.

http://www.zbp.pl/photo/jacek/klub_polska_2015_polska_2030/ZBP_V.03.pdf.

NIK o dostosowaniu stron internetowych do potrzeb osób $z$ niepetnosprawnościami, NIK, 10.02.2016, https://www.nik.gov.pl/aktualnosci/nik-o-dostosowaniu-stron-internetowych-do-potrzeb-osob-z-niepelnosprawnosciami.html.

Osoba niepetnosprawna aktywnym uczestnikiem życia społecznego i zawodowego, Projekt wspólfinansowany ze środków Unii Europejskiej w ramach europejskiego funduszu społecznego, Rzeszów 2014, http://www.rops.rzeszow.pl/dokumenty/badania/5_ niepelnosprawni.pdf.

Po 42. sesji Rady Miasta Gdyni, Gdynia. Moje miasto, 6.05.2010, https://www.gdynia.pl/ mieszkaniec/951-551-2010-0507-2010-05-13,3239/po-42-sesji-rady-miasta-gdyni,397335.

Rząd przyjąt projekt ustawy o dostępności cyfrowej stron internetowych i aplikacji mobilnych podmiotów publicznych, gov.pl, 19.12.2018, https://www.gov.pl/web/cyfryzacja/ rzad-przyjal-projekt-ustawy-o-dostepnosci-cyfrowej-stron-internetowych-i-aplikacji-mobilnych-podmiotow-publicznych. 
Anna Rogacka-Łukasik

Uzasadnienie do projektu ustawy o dostępności cyfrowej stron internetowych i aplikacji mobilnych podmiotów publicznych, Sejm Rzeczpospolitej Polskiej, 18.02.2019, https://www.sejm.gov.pl/sejm8.nsf/druk.xsp?nr=3119.

\section{Inne}

Ocena skutków regulacji zawartych w rządowym projekcie ustawy o dostępności cyfrowej stron internetowych i aplikacji mobilnych podmiotów publicznych (druk sejmowy nr 3119), Biuro Analiz Sejmowych Kancelarii Sejmu, Warszawa, 16 stycznia $2019 \mathrm{r}$. 